\title{
Determination of Carbonyl Compounds in Cigarette Mainstream Smoke. The CORESTA 2010 Collaborative Study and Recommended Method*
}

\author{
by \\ Michael Intorp ${ }^{1}$, Steve Purkis ${ }^{2}$, and Wendy Wagstaff ${ }^{3}$ \\ ${ }^{1}$ Imperial Tobacco Group, Albert-Einstein-Ring 7, 22761 Hamburg, Germany \\ ${ }^{2}$ Imperial Tobacco Limited, PO Box 525, Winterstock Road, Bristol BS99 1LQ, United Kingdom \\ ${ }^{3}$ Labstat International ULC, 262 Manitou Drive, Kitchener, Ontario N2C 1L3, Canada
}

\section{SUMMARY}

A recommended method has been developed and published by CORESTA, applicable to the quantification of selected carbonyl compounds (acetaldehyde, formaldehyde, acetone, acrolein, methyl ethyl ketone, crotonaldehyde, propionaldehyde and butyraldehyde) in cigarette mainstream smoke. The method involved smoke collection in impinger traps, derivatisation of carbonyls with 2,4-dinitrophenylhydrazine (DNPH), separation of carbonyl hydrazones by reversed phase high performance liquid chromatography and detection by ultra violet or diode array.

At the start of the process it was determined that most laboratories participating in the CORESTA Special Analytes Sub-Group (SASG) used a similar method involving such derivatisation and so this was chosen as the basis of the recommended method. Initial joint experiments, specific experiments by single laboratories and ongoing discussions addressed some methodological aspects that needed to be considered before moving to a recommended method.

As a first step, a joint experiment by 17 laboratories was carried out in 2009-2010 that investigated three features of the methodology on two reference cigarettes (3R4F and CM6) considered most important by SASG members. These were the volume of the impinger solution (25 or $35 \mathrm{~mL}$ ); the type of mineral acid (perchloric or phosphoric) used to initiate the derivatisation and the time of derivatisation ( 5 or $30 \mathrm{~min}$ ) before terminating the reaction with Trizma ${ }^{\mathrm{TM}}$ base. Overall, it was concluded that these studied parameters in the methodology seemed to have little effect on the overall yield data, compared to the underlying variability among laboratories. The $25 \mathrm{~mL}$ impinger solutions appeared to give somewhat higher yields, al- though not with statistically significant differences, than those obtained when using $35 \mathrm{~mL}$ solutions.

Some laboratories volunteered to carry out other investigations, for example, to confirm the identity of both the $E$ and $Z$-isomeric acetaldehyde hydrazone peaks within the chromatogram of smoke carbonyls and to investigate methodology factors influencing the hydrazone isomerisation.

The CORESTA recommended method (CRM) was produced through a final collaborative experiment involving 15 laboratories from 11 countries using 7 linear and 8 rotary smoking machines. Some notes are included in the CRM to inform other laboratories that might wish to adopt the method, concerning the main features that need to be well controlled to provide data as robust as possible and to provide similar repeatability and reproducibility data.

Statistical evaluations were made according to ISO 5725 recommendations and are included. As expected from previous work on other smoke components, the levels of reproducibility of carbonyl yields among laboratories are much greater than the levels found for "tar", nicotine and carbon monoxide and given in the equivalent ISO standards. When expressing the reproducibility $(\mathrm{R})$ value as a percentage of the mean yield among-laboratories and across all of the studied products, values ranged from $67-125 \%$ for formaldehyde; from $24-55 \%$ for acetaldehyde; from $41-108 \%$ for acetone; from $45-73 \%$ for acrolein; $31-75 \%$ for propionaldehyde; from $63-140 \%$ for crotonaldehyde; from $62-90 \%$ for 2-butanone and from $42-58 \%$ for butyraldehyde. The lowest "tar" yielding product gave the most variable data. These levels are generally in line with those determined for selected volatiles. [Beitr. Tabakforsch. Int. 25 (2012) 361-374] 


\section{ZUSAMMENFASSUNG}

Von der CORESTA wurde zur Bestimmung von ausgewählten Carbonyl-Verbindungen (Acetaldehyd, Formaldehyd, Aceton, Acrolein, Methylethylketon, Crotonaldehyd, Propionaldehyd und Butyraldehyd) im Hauptstromrauch von Zigaretten eine Methode entwickelt und veröffentlicht. Die Methode basiert auf dem Sammeln des Rauchs in Flüssigfallen, Derivatisierung der Carbonyle mit 2,4-Dinitrophenylhydrazin (DNPH), Abtrennung der Carbonylhydrazone mittels HPLC und Nachweis durch UV-Strahlen bzw. eine Diodenzelle.

Die meisten der in der CORESTA Special Analytes SubGroup teilnehmenden Laboratorien nutzten bereits eine ähnliche Derivatisierungsmethode, sodass diese als Grundlage für die Methodenentwicklung verwendet wurde. Erste gemeinsame Experimente und spezielle Experimente einzelner Laboratorien sowie regelmäßige Diskussionen befassten sich mit einigen methodischen Aspekten, die vor Etablierung einer Methode beachtet werden mussten.

In einem ersten Schritt führten 17 Laboratorien in den Jahren 2009 und 2010 gemeinsame Versuche an zwei Referenzzigaretten (3R4F und CM6) durch, bei denen die drei wichtigsten Einflussfaktoren auf die Methode untersucht werden sollten. Hierbei wurde ermittelt, ob das Volumen in der Flüssigfalle 25 oder $35 \mathrm{~mL}$ betragen sollte, welche Säure (Perchlor- oder Phosphorsäure) zur Initialisierung der Derivatisierung verwendet werden sollte, und wieviel Zeit ( 5 oder $30 \mathrm{~min}$ ) für die Derivatisierung zur Verfügung stehen sollte, bevor die Reaktion mit TrizmaTM beendet wurde. Diese untersuchten methodischen Parameter schienen auf die erzielten Werte im Vergleich zu den festgestellten Unterschieden zwischen den einzelnen Laboratorien nur untergeordnete Bedeutung zu haben. Bei der Flüssigfalle traten bei $25 \mathrm{~mL}$ Volumen im Vergleich zu $35 \mathrm{~mL}$ etwas höhere Werte auf, die jedoch nicht statistisch signifikant waren.

Einige Laboratorien erklärten sich bereit, weitere Untersuchungen durchzuführen, wie z.B. den Nachweis, dass die $E$ - und $Z$-Isomere von Acetaldehydhydrazon im Chromatogramm der im Rauch enthaltenen Carbonyle zu identischen Peaks führten, oder die Beurteilung von methodischen Faktoren, die die Hydrazonisomerisierung beeinflussen könnten.

In einem abschließenden Experiment wurde die CORESTA-Methode entwickelt, wobei 15 Laboratorien aus 11 Staaten unter Verwendung von 7 linearen und 8 rotierenden Rauchmaschinen teilnahmen. Laboratorien, die diese Methode einführen wollen, finden in dieser CORESTA-Methode eine umfangreiche Beschreibung der relevanten Einflussfaktoren, die genau zu beachten sind, um möglichst robuste Daten bei vergleichbarer Reproduzier- und Wiederholbarkeit zu erhalten.

Die statistische Auswertung erfolgte nach ISO 5725 und ist in diesem Bericht enthalten. Wie nach früheren Arbeiten mit anderen Tabakrauchkomponenten zu erwarten war, sind die ermittelten Reproduzierbarkeiten der Carbonyle im Vergleich zwischen den Laboratorien erheblich größer als die Werte, die für Teer, Nikotin und Kohlenstoffmonoxid in den entsprechenden ISO-Standard-Methoden genannt werden. Die Reproduzierbarkeiten (R) ausgedrückt in Prozent der Mittelwerte aller Laboratorien liegen für alle untersuchten Produkte zwischen $67-125 \%$ bei Formaldehyd, $24-55 \%$ bei Acetaldehyd, $41-108 \%$ bei Aceton, $45-73 \%$ bei Acrolein, $31-75 \%$ bei Propionaldehyd, $63-140 \%$ bei Crotonaldehyd, $62-90 \%$ bei $2-B u t a n o n$ und $42-58 \%$ bei Butyraldehyd. Die Produkte mit den niedrigsten Kondensatgehalten lieferten dabei die Werte mit den größten Schwankungen. Diese Werte sind vergleichbar $\mathrm{zu}$ denen, die für ausgewählte volatile Verbindungen gemessen wurden. [Beitr. Tabakforsch. Int. 25 (2012) 361-374]

\section{RESUME}

Le CORESTA a développé et publié une méthode recommandée pour la quantification de certains carbonyles dans la fumée principale de la cigarette (acétaldéhyde, formaldéhyde, acétone, acroléine, 2-butanone, crotonaldéhyde, propionaldéhyde et butyraldéhyde). Cette méthode implique le piégeage de la fumée dans des barboteurs, la dérivation des carbonyles avec le 2,4-dinitrophenylhydrazine (DNPH), la séparation des carbonyles sous forme hydrazone par chromatographie liquide haute performance en phase inversée et la détection par Ultra Violet ou barrettes de diode.

$\mathrm{Au}$ début de la démarche de développement, il a été observé que la plupart des laboratoires participant au sousgroupe CORESTA " Special Analytes " utilisait une méthode similaire de dérivation de telle sorte que celle-ci a été choisie comme base pour la méthode recommandée. Les essais collaboratifs préliminaires, les expériences spécifiques menées par certains laboratoires et les divers échanges ont mis l'accent sur les aspects méthodologiques à prendre en compte avant d'aboutir à une méthode recommandée.

Dans un premier temps, un essai collaboratif mené par 17 laboratoires en 2009-2010 sur 2 cigarettes de référence (3R4F et CM6) a porté sur les trois aspects de la méthodologie considérés comme les plus importants par les membres du SASG. Ces aspects étaient le volume de la solution de piégeage $(25 \mathrm{~mL}$ ou $35 \mathrm{~mL})$, le type d'acide minéral (perchlorique ou phosphorique) utilisé pour initier la dérivation et le temps de dérivation ( 5 ou $30 \mathrm{~min}$ ) avant de mettre fin à la réaction avec la base Trizma. Globalement, il a été conclut que les paramètres étudiés dans la méthodologie semblaient avoir peu d'effet sur les valeurs globales de rendement, comparés aux variabilités observées parmi chaque laboratoire. Un volume de solution de piégeage de $25 \mathrm{~mL}$ semble quelque peu augmenter les rendements, bien que les différences ne soient pas statistiquement significatives comparées à un volume de $35 \mathrm{~mL}$.

Quelques laboratoires se sont portés volontaires pour effectuer d'autres investigations, comme par exemple, la confirmation de l'identité des pics des isomères $E$ - et $Z$ - des dérivés d'acétaldéhyde-hydrazone apparus sur le chromatogramme des carbonyles de la fumée et la recherche des facteurs méthodologique influençant l'isomérisation.

La méthode recommandée du CORESTA a été finalisée suite à une étude collaborative finale impliquant 15 laboratoires issus de 11 pays différents, et utilisant 7 
machines à fumer linéaires et 8 machines à fumer rotatives. Certaines consignes ont été inclues dans la méthode recommandée pour informer d'autres laboratoires qui désireraient adopter cette méthode. Parmi ces consignes, il y a les caractéristiques principales qu'il convient de bien maîtriser pour pouvoir fournir des données aussi fiables que possible, avec une répétabilité et une reproductibilité similaires.

Les évaluations statistiques ont été réalisées selon les recommandations de la norme ISO 5725 et ont été inclues. Comme observé lors de précédentes études sur d'autres composés de la fumée, les niveaux de reproductibilité des rendements de carbonyles des différents laboratoires sont plus élevés que les niveaux observés pour les analyses de goudrons, nicotine et monoxyde de carbone tels qu'indiqués dans les normes ISO correspondantes. Lorsque les valeurs de reproductibilité sont exprimées en \% du rendement moyen des laboratoires pour tous les produits étudiés, les valeurs varient de 67 à $125 \%$ pour le formaldéhyde, de 24 à $55 \%$ pour l'acétaldéhyde, de 41 à $108 \%$ pour l'acétone, de 45 à $73 \%$ pour l'acroléine, de 31 à $75 \%$ pour le propionaldéhyde, de 63 à $140 \%$ pour le crotonaldéhyde, de 62 à $90 \%$ pour le 2-butanone et de 42 à $58 \%$ pour le butyraldéhyde. Le produit dont le rendement en goudrons était le plus bas a montré les résultats les plus variables. Ces niveaux sont en ligne avec ceux observés pour les composés volatiles. [Beitr. Tabakforsch. Int. 25 (2012) 361-374]

\section{INTRODUCTION}

This work followed on from the development of a CRM used to measure selected volatiles $(1,2)$ in cigarette mainstream smoke. Carbonyls have been measured by various methods as reported in the literature (3-9). A review of currently used methodology during a previous CORESTA Special Analytes Sub-Group (SASG) study, carried out in 2006 (9), indicated that the majority of laboratories were using a method involving the derivatisation of carbonyls with 2,4-dinitrophenylhydrazine (DNPH), separation of carbonyl hydrazones by reversed phase high performance liquid chromatography (HPLC) and detection by ultra violet (UV) or diode array (DAD). A reported study on direct collection in a glass syringe provided very similar smoke yields on reference cigarettes to those found by the DNPH method (8).

This paper outlines an initial joint experiment that was carried out by SASG members on the CORESTA Monitor Test Piece (CM6) and the 3R4F Kentucky reference cigarettes (10). Several key parts of the methodology were investigated in detail to evaluate their effects on smoke yields and the learning exercise provided additional clarification and direction in discussions towards the planning of the recommended method.

Further small experiments were carried out by individual SASG members on the effect of reaction conditions on the formation of isomeric hydrazone derivatives and the identification of both $E$ - and $Z$-isomers of the acetaldehyde hydrazone as major peaks in the chromatogram from cigarette smoke.

The work also describes details of a CORESTA collabora- tive study leading to a recommended method (11) for the determination of carbonyls in cigarette mainstream smoke. The statistical analysis of the yield data from 15 laboratories including repeatability and reproducibility data is presented. The report describes key components of the recommended method and provides additional notes to inform other laboratories about some of the main features that need to be well controlled to provide data as robust and consistent as the data presented herein.

\section{EXPERIMENTAL}

\section{Participating laboratories}

A summary of the fifteen participating laboratories and their principal investigators in the collaborative study is given below.

\begin{tabular}{ll}
\hline $\begin{array}{l}\text { Participating laboratories and } \\
\text { institutions }\end{array}$ & Principal investigators \\
\hline $\begin{array}{l}\text { British American Tobacco (UK) } \\
\text { CNTC Beijing (China) }\end{array}$ & $\begin{array}{l}\text { Jun Zhoud / Jana Ticha } \\
\text { Hongwei Hou }\end{array}$ \\
CNTC QSTC (China) & $\begin{array}{l}\text { Fuwei Xie } \\
\text { CNTC ZTRI (China) }\end{array}$ \\
$\begin{array}{c}\text { Chemisches und Veterinär- } \\
\text { landesuntersuchungsamt }\end{array}$ & Jürgen Hahn \\
Sigmaringen (Germany) & \\
Filtrona International (UK) & Mike Taylor \\
Imperial Tobacco Group / & Sandrine Destruhaut \\
Altadis (France) & Sandra Otte / Michael Intorp \\
Imperial Tobacco Group / & (SASG coordinator) / Steve \\
Reemtsma (Germany) & Purkis (SASG coordinator) \\
Japan Tobacco (Japan) & Takatsugu Hyodo \\
KT\&G (Korea) & Hyo-Keun Kim \\
Labstat (Canada) & Pete Joza / Wendy Wagstaff \\
Philip Morris Research & (Statistical analysis) \\
Laboratories (Germany) & Joerg Diekmann \\
Philip Morris International & Michel Rotach \\
(Switzerland) & \\
Philip Morris Sampoerna & Antonius \\
(Indonesia) & Janell Rowe / Brad Rhoades \\
R J Reynolds (USA) & \\
\hline
\end{tabular}

\section{Joint experiment protocol}

After conditioning (12), test cigarettes (CM6 and 3R4F) were smoked on a smoking machine that had been fitted with impingers and adjusted to standardised conditions (13). The unfiltered mainstream tobacco smoke was 'scrubbed' of volatile carbonyls by passing each puff through an impinger system containing a solution of 2,4dinitrophenylhydrazine dissolved in acetonitrile. A mineral acid was also present to push the reaction towards full derivatisation. An aliquot of the reacted DNPH-smoke extract was diluted with $1 \%$ Trizma $^{\mathrm{TM}}$ base in aqueous acetonitrile to terminate the reaction after a selected reaction time and then syringe-filtered. The samples were subjected to reverse phase HPLC and carbonyl hydrazones were detected and quantified by UV or DAD. 
Table 1. Joint experiment design.

\begin{tabular}{|c|c|c|c|c|}
\hline Group & \begin{tabular}{|c|}
$\begin{array}{c}\text { No. of } \\
\text { labs }\end{array}$ \\
\end{tabular} & Design & \begin{tabular}{|c|}
$\begin{array}{c}\text { Volume of } \\
\text { solution }(\mathrm{mL})\end{array}$ \\
\end{tabular} & $\begin{array}{l}\text { Mineral } \\
\text { acid } \\
\end{array}$ \\
\hline \multirow{2}{*}{$\begin{array}{l}\text { Group A } \\
\left(25 / 35 \mathrm{~mL} ; \mathrm{HClO}_{4}\right)\end{array}$} & 4 & 1 & 25 & $\mathrm{HClO}_{4}$ \\
\hline & 4 & 2 & 35 & $\mathrm{HClO}_{4}$ \\
\hline \multirow{2}{*}{$\begin{array}{l}\text { Group B } \\
\left(25 / 35 \mathrm{~mL} ; \mathrm{H}_{3} \mathrm{PO}_{4}\right)\end{array}$} & 4 & 1 & 25 & $\mathrm{H}_{3} \mathrm{PO}_{4}$ \\
\hline & 4 & 2 & 35 & $\mathrm{H}_{3} \mathrm{PO}_{4}$ \\
\hline \multirow{2}{*}{$\begin{array}{l}\text { Group C } \\
\left(25 \mathrm{~mL} ; \mathrm{HClO}_{4} / \mathrm{H}_{3} \mathrm{PO}_{4}\right)\end{array}$} & 5 & 1 & 25 & $\mathrm{HClO}_{4}$ \\
\hline & 5 & 2 & 25 & $\mathrm{H}_{3} \mathrm{PO}_{4}$ \\
\hline \multirow{2}{*}{$\begin{array}{l}\text { Group D } \\
\left(35 \mathrm{~mL} ; \mathrm{HClO}_{4} / \mathrm{H}_{3} \mathrm{PO}_{4}\right)\end{array}$} & 4 & 1 & 35 & $\mathrm{HClO}_{4}$ \\
\hline & 4 & 2 & 35 & $\mathrm{H}_{3} \mathrm{PO}_{4}$ \\
\hline
\end{tabular}

Three factors were considered for investigation, that is, the volume of trapping solution in two impingers (25 or $35 \mathrm{~mL}$ ); the mineral acid (phosphoric; $\mathrm{H}_{3} \mathrm{PO}_{4}$; or perchloric; $\mathrm{HClO}_{4}$ ) required for the derivatisation step and the completion time ( 5 or $30 \mathrm{~min}$ ) of the derivatisation step.

In order to reduce the workload on each of the 17 participating laboratories, they were split as evenly as possible into four different groups (A-D) where each group maintained either (a) the same volume of trapping solution or (b) the same mineral acid for derivatisation according to the design shown in Table 1.

Each laboratory applied the required level of trapping volume and mineral acid type, then carried out the derivatisation. They completed the reaction on one replicate after $5 \mathrm{~min}$ and on another replicate after $30 \mathrm{~min}$. This process was carried out three times to produce a total of three replicates for each reaction time on both the CM6 and 3R4F test samples.

\section{Some studies on carbonyl derivatisation}

Some experiments were carried out by single laboratories after discussions within the SASG.

- One laboratory carried out LC-MS/MS analysis to confirm that a major peak in the HPLC chromatogram of cigarette smoke, close to the acetaldehyde hydrazone was the corresponding stereo isomer.

- The influence of phosphoric acid on the formation of both of the acetaldehyde hydrazone isomers was investigated in another laboratory. The concentration of the acetaldehyde hydrazone, bought for the calibration solutions was maintained at the same level in a series of trials. In the first trial, both 2,4-DNPH and phosphoric acid were added. In another 3 trials, different dilutions of phosphoric acid were performed then made up with
Table 2. Cigarette test samples.

\begin{tabular}{|c|c|c|}
\hline $\begin{array}{c}\text { Sample } \\
\text { code }\end{array}$ & Tobacco blend and design & $\begin{array}{c}\text { NFDPM yield } \\
(\mathrm{mg})\end{array}$ \\
\hline Sample 1 & $\begin{array}{l}\text { Dark air cured blend / } \\
\text { Cellulose acetate (CA) filter }\end{array}$ & 10 \\
\hline Sample 2 & $\begin{array}{l}\text { American blend / } \\
\text { CA filter }\end{array}$ & 6 \\
\hline Sample 3 & $\begin{array}{l}\text { Virginia blend / } \\
\text { CA filter }\end{array}$ & 8 \\
\hline Sample 4 & $\begin{array}{l}\text { American blend / } \\
\text { CA filter including charcoal }\end{array}$ & 1 \\
\hline Sample 5 & $\begin{array}{l}\text { American blend / } \\
\text { CA filter including charcoal }\end{array}$ & 10 \\
\hline CM6 & $\begin{array}{l}\text { CORESTA monitor / } \\
\text { Virginia blend / CA filter }\end{array}$ & 15 \\
\hline 1R5F & $\begin{array}{l}\text { Kentucky Reference / } \\
\text { American blend / CA filter }\end{array}$ & 2 \\
\hline 3R4F & $\begin{array}{l}\text { Kentucky Reference / } \\
\text { American blend / CA filter }\end{array}$ & 8 \\
\hline
\end{tabular}

$5 \mathrm{~mL}$ of Trizma $^{\mathrm{TM}}$ base to the same final volume $(10 \mathrm{~mL})$. The degree of isomerisation of the purchased acetaldehyde hydrazone to the corresponding stereo isomer was calculated in the different trials in accordance with the method for the regular preparation of calibration solutions and by applying the usual calibration curves and the usual chromatographic conditions.

\section{Collaborative study protocol}

The method was agreed upon by the SASG members based on the learning from the joint experiment, experiments from single laboratories and subsequent discussions. It was used for a collaborative study on 8 test cigarettes to provide robust repeatability and reproducibility data for the selected carbonyls (acetaldehyde, formaldehyde, acetone, acrolein, methyl ethyl ketone, crotonaldehyde, propionaldehyde and butyraldehyde) as determined in cigarette mainstream smoke that are included in the published method (11).

The test samples listed in Table 2 were used in both this and the previously described collaborative study on selected volatiles (2). Samples 1-5 were commercially available cigarettes provided by various manufacturers to represent a range of Nicotine Free Dry Particulate Matter (NFDPM) yields as determined by the ISO smoking regime and a range of blend and cigarette design styles to complement the 3 reference products (CM6, 1R5F and 3R4F). Laboratories smoked 5 replicates of the 8 test samples using a randomised design within 8 runs per experiment.

Table 3. Summary of joint experiment data. Carbonyl yield in $\mu \mathrm{g} /$ cigarette.

\begin{tabular}{|c|c|c|c|c|c|c|c|c|c|}
\hline Sample & & $\begin{array}{c}\text { Form- } \\
\text { aldehyde }\end{array}$ & $\begin{array}{c}\text { Acet- } \\
\text { aldehyde }\end{array}$ & Acetone & Acrolein & $\begin{array}{l}\text { Propion- } \\
\text { aldehyde }\end{array}$ & $\begin{array}{c}\text { Croton- } \\
\text { aldehyde }\end{array}$ & 2-Butanone & $\begin{array}{l}\text { n-Butyr- } \\
\text { aldehyde }\end{array}$ \\
\hline CM6 & $\begin{array}{l}\text { Mean } \\
\text { SD }\end{array}$ & $\begin{array}{l}47.1 \\
15.1\end{array}$ & $\begin{array}{l}649.1 \\
134.7\end{array}$ & $\begin{array}{r}263.9 \\
48.4\end{array}$ & $\begin{array}{l}64.7 \\
16.9\end{array}$ & $\begin{array}{r}52.2 \\
8.3\end{array}$ & $\begin{array}{r}21.5 \\
7.6\end{array}$ & $\begin{array}{l}57.2 \\
16.6\end{array}$ & $\begin{array}{r}37.1 \\
8.3\end{array}$ \\
\hline 3R4F & $\begin{array}{c}\text { Mean } \\
\text { SD }\end{array}$ & $\begin{array}{r}21.5 \\
7.8\end{array}$ & $\begin{array}{l}540.3 \\
135.3\end{array}$ & $\begin{array}{r}214.1 \\
43.4\end{array}$ & $\begin{array}{l}49.0 \\
14.1\end{array}$ & $\begin{array}{r}42.6 \\
8.0\end{array}$ & $\begin{array}{r}13.2 \\
5.2\end{array}$ & $\begin{array}{l}47.2 \\
14.6\end{array}$ & $\begin{array}{r}26.7 \\
6.2\end{array}$ \\
\hline
\end{tabular}


Table 4. Results from calibration solutions of different dilutions.

\begin{tabular}{|c|c|c|c|c|c|c|}
\hline Trial No. & 2,4-DNPH & $\begin{array}{l}\text { Phosphoric acid } \\
\text { solution }^{\text {a }}\end{array}$ & $\begin{array}{l}\text { Trizma }^{\mathrm{TM}} \\
\text { base }\end{array}$ & $\begin{array}{c}\text { Effect of adding reagents on the } \\
\text { composition of the calibration } \\
\text { solution }\end{array}$ & $\begin{array}{c}\text { Acetaldehyde } \\
\text { hydrazone }(\mu \mathrm{g} / \mathrm{mL}) \\
\text { stereo isomer }\end{array}$ & $\begin{array}{l}\text { Acetaldehyde } \\
\text { hydrazone } \\
(\mu \mathrm{g} / \mathrm{mL})\end{array}$ \\
\hline & no & no & no & $\begin{array}{l}\text { initial calibration } \\
\text { solution }(\mu \mathrm{g} / \mathrm{mL})\end{array}$ & 0 & 3.059 \\
\hline 1 & added & $\begin{array}{l}100 \% \\
\text { added }\end{array}$ & added & $\begin{array}{l}\text { concentration }(\mu \mathrm{g} / \mathrm{mL}) \\
\% \text { distribution }\end{array}$ & $\begin{array}{c}0.858 \\
28\end{array}$ & $\begin{array}{c}2.810 \\
92\end{array}$ \\
\hline 2 & no & $\begin{array}{l}100 \% \\
\text { added }\end{array}$ & added & $\begin{array}{c}\text { concentration }(\mu \mathrm{g} / \mathrm{mL}) \\
\% \text { distribution }\end{array}$ & $\begin{array}{l}0.800 \\
26\end{array}$ & $\begin{array}{c}2.692 \\
88\end{array}$ \\
\hline 3 & no & $\begin{array}{l}100 \% \text { diluted } \\
10 \text { times }\end{array}$ & added & $\begin{array}{c}\text { concentration }(\mu \mathrm{g} / \mathrm{mL}) \\
\% \text { distribution }\end{array}$ & $\begin{array}{c}0.827 \\
27\end{array}$ & $\begin{array}{c}2.721 \\
89\end{array}$ \\
\hline 4 & no & $\begin{array}{l}100 \% \text { diluted } \\
100 \text { times }\end{array}$ & added & $\begin{array}{l}\text { concentration }(\mu \mathrm{g} / \mathrm{mL}) \\
\% \text { distribution }\end{array}$ & $\begin{array}{c}0.830 \\
27\end{array}$ & $\begin{array}{c}2.742 \\
90\end{array}$ \\
\hline
\end{tabular}

a $100 \%$ phosphoric acid solution refers to an acid concentration $(0.35 \%$; v/v) during the preparation of the reaction solution given in the carbonyls CRM (11).

\section{RESULTS}

\section{Joint experiment}

It is not the intention to report the full analyses from the joint experiment but to concentrate discussions on the collaborative study. A summary of carbonyl yield data from the joint experiment is given in Table 3.

\section{Hydrazone isomerisation and recovery experiments}

Table 4 gives the recoveries of both isomers of the acetaldehyde hydrazone after allowing the isomerisation of the purchased hydrazone in the presence of different levels of phosphoric acid. This experiment was carried out in only one laboratory.

\section{Collaborative study data}

Analytical yields of the selected carbonyls were obtained and mean yields are given in Tables 5.1 to 5.8 (calculated after exclusion of outliers as described later, for tables see pages 371-373). These need to be below the range of levels found in the analysed products to ensure that the method is fit for purpose. Each laboratory provided information on the limits of detection (LOD) and limits of quantification (LOQ), with the range summarised as maximum and minimum values (Table 6). There was no requirement that LOQs or LODs were measured in the same way at different laboratories and this is reflected in the wide range given.
It can be noted that there was no indication that the method of determining LODs or LOQs lead to lower or higher levels of outlier or excluded data. Excellent recovery rates were given by all laboratories for each of the carbonyls.

\section{DATA ANALYSIS}

\section{Joint experiment}

Three features of the methodology were identified for particular study within the initial joint experiment. These were the volume of the impinger solution $(25$ or $35 \mathrm{~mL}$ ); the mineral acid used (perchloric or phosphoric) and the time of derivatisation ( 5 or $30 \mathrm{~min}$ ). The results of the laboratory groups studying the various method parameters, as set out in the protocol, are not given individually herein because they were not statistically significantly different. The most extreme differences are set out in Table 7.

Statistically significant higher yields were only found for acetaldehyde, acetone, acrolein and propionaldehyde with the $25 \mathrm{~mL}$ rather than the $35 \mathrm{~mL}$ trapping solution volume. There was also some indication that the variation in replicate yields using the $25 \mathrm{~mL}$ trapping solution volume appeared to be greater than that of the replicates using the $35 \mathrm{~mL}$ volume. This was statistically significant for the 4 analytes given in Table 7 . A volume of $35 \mathrm{~mL}$ was used in the CRM (11).

Neither the choice of mineral acid (perchloric or phosphoric acid) nor the derivatisation completion time (5 versus 30

Table 6. Limits of quantification (LOQ) and limits of detection (LOD) in $\mu \mathrm{g} / \mathrm{cig}$.

\begin{tabular}{|c|c|c|c|c|c|c|c|c|c|}
\hline & & $\begin{array}{l}\text { Form- } \\
\text { aldehyde }\end{array}$ & $\begin{array}{c}\text { Acet- } \\
\text { aldehyde }\end{array}$ & Acetone & Acrolein & $\begin{array}{l}\text { Propion- } \\
\text { aldehyde }\end{array}$ & $\begin{array}{l}\text { Croton- } \\
\text { aldehyde }\end{array}$ & 2-Butanone & $\begin{array}{l}\text { n-Butyr- } \\
\text { aldehyde }\end{array}$ \\
\hline \multirow{2}{*}{ LOQ } & $\min$ & 0.01 & 0.022 & 0.015 & 0.015 & 0.017 & 0.018 & 0.01 & 0.015 \\
\hline & $\max$ & 2.00 & 16.4 & 4.3 & 4.3 & 5.1 & 1.6 & 5.0 & 4.0 \\
\hline \multirow{2}{*}{ LOD } & $\min$ & 0.003 & 0.007 & 0.005 & 0.005 & 0.005 & 0.005 & 0.003 & 0.005 \\
\hline & $\max$ & 0.90 & 1.2 & 1.0 & 1.0 & 1.0 & 1.1 & 1.2 & 1.2 \\
\hline \multirow{2}{*}{$\begin{array}{l}\text { Recovery } \\
(\%)\end{array}$} & $\min$ & 86 & 95 & 91 & 91 & 89 & 69 & 73 & 88 \\
\hline & $\max$ & 138 & 129 & 116 & 116 & 116 & 119 & 107 & 111 \\
\hline
\end{tabular}


Table 7. Statistically significant yield differences from joint experiment in $\mu \mathrm{g} / \mathrm{cig}$.

\begin{tabular}{|c|c|c|c|c|}
\hline Sample & Acetaldehyde & Acetone & Acrolein & Propionaldehyde \\
\hline $\begin{array}{l}\text { CM6 } \\
\text { mean from all experiments }\end{array}$ & 649 & 264 & 65 & 52 \\
\hline $\begin{array}{l}\text { CM6 } \\
\text { phosphoric acid / 30min / 25mL }\end{array}$ & 813 & - & 82 & 61 \\
\hline $\begin{array}{l}\text { CM6 } \\
\text { phosphoric acid / 30min / 35mL }\end{array}$ & 581 & - & 61 & 52 \\
\hline $\begin{array}{l}\text { 3R4F } \\
\text { mean from all experiments }\end{array}$ & 540 & 214 & 49 & 43 \\
\hline $\begin{array}{l}\text { 3R4F } \\
\text { phosphoric acid / 30min / } 25 \mathrm{~mL}\end{array}$ & 698 & 252 & 64 & - \\
\hline $\begin{array}{l}\text { 3R4F } \\
\text { phosphoric acid / 30min / 35mL }\end{array}$ & 476 & 203 & 46 & - \\
\hline
\end{tabular}

min) had any impact on the significance of this difference. The most extreme cases are given in Table 7.

- The choice of mineral acid (phosphoric acid) for the CRM was therefore made on the basis of health and safety reasons.

- In some laboratory set-ups, $8-10 \mathrm{~min}$ is required to remove impingers from the smoking machine and add Trizma ${ }^{\mathrm{TM}}$ base, so a derivatisation time of 30 min would seem more practically relevant than $5 \mathrm{~min}$ and was included in the collaborative study and CRM.

Any influence of smoking machine type on yield data was not studied in the initial joint experiment.

\section{Smoke collection issues}

Some important issues regarding impingers for smoke collection were observed during the joint experiment.

- The CRM notes point out that it is important that the impinger geometry should be such that 2 traps collect $>95 \%$ of carbonyls and that a coarse frit be recommended or an orifice setup be used.

- For certain analytes (formaldehyde / acetone / propionaldehyde) and cigarette types of high yields (CM6) some laboratories found that a third impinger was necessary for $>95 \%$ trapping efficiency, particularly for laboratories that used impinger orifices rather than frits.

- There can be potential problems of frit blocking during continual use and the frit size will impact on how often they need cleaning. Frits can be soaked overnight in acetonitrile even though they eventually have to be cleaned in a muffle furnace. The frit size also has an impact on the ease of puff draw and should be checked before use. These discussions led to some laboratories changing to orifice holes in the impinger system.

- The trapping volume and impinger geometry are interdependent. When comparing 25 versus $35 \mathrm{~mL}$ impinger trapping volumes there is potential for pressure drop changes leading to differences in puff profiles and so careful adjustments to puff volumes may be required.

\section{DNPH derivatisation issues}

The CRM includes a recommendation for the DNPH recrystallisation procedure since different suppliers often provide DNPH with different water levels and laboratories can potentially use different solvents for re-crystallisation (e.g., ethanol and acetonitrile). A technical note describes how the laboratories determined whether any DNPH derivative was measured in the last of a series of traps. If none can be found then the trapping efficiency of the earlier traps is considered sufficient. As long as an excess of DNPH is used and un-reacted DNPH is detected in the chromatogram then a complete reaction is assumed.

The acetaldehyde hydrazone has been reported to have a propensity to isomerise depending on its method of preparation (14). When carbonyl calibration standards are prepared in acetonitrile only one isomer is present in the HPLC chromatogram (Figure 1).

When standards are prepared in acetonitrile with mineral acid present then both stereo-isomers are observed in the chromatogram (not shown). Smoke samples prepared in a similar way give an acetaldehyde peak preceded by a minor peak. LC-MS/MS has been used to confirm the identity of the minor peak as being the stereo isomer of the acetaldehyde hydrazone. The HPLC chromatogram of the smoke profile is given in Figure 2.

Data from Table 4 show that the addition of phosphoric acid created a mixture of stereo isomers of the acetaldehyde hydrazone and this was confirmed by mass spectral identifications. The acid concentration plays a minor role in the conversion rate. The CRM includes both stereo isomers in the calculations for acetaldehyde to avoid an underestimation of smoke yields.

The minor carbonyls may also form additional isomers but these are not easily separated from interfering components in the matrix. Relatively high recovery rates from data of one isomer for each of the other carbonyls except acetaldehyde were found in the region of $70-120 \%$ as shown in Table 6. Such recoveries are acceptable according to EU guidelines in other testing for pesticide residues (15) and justify using yields from only the one isomer in the collaborative study and CRM.

\section{Collaborative study}

The learning from the joint and single laboratory experiments and SASG discussions were incorporated in the CRM. The collaborative study provided data from 15 laboratories to produce the means yields and repeatability / reproducibility data. 14 laboratories collected data for all 


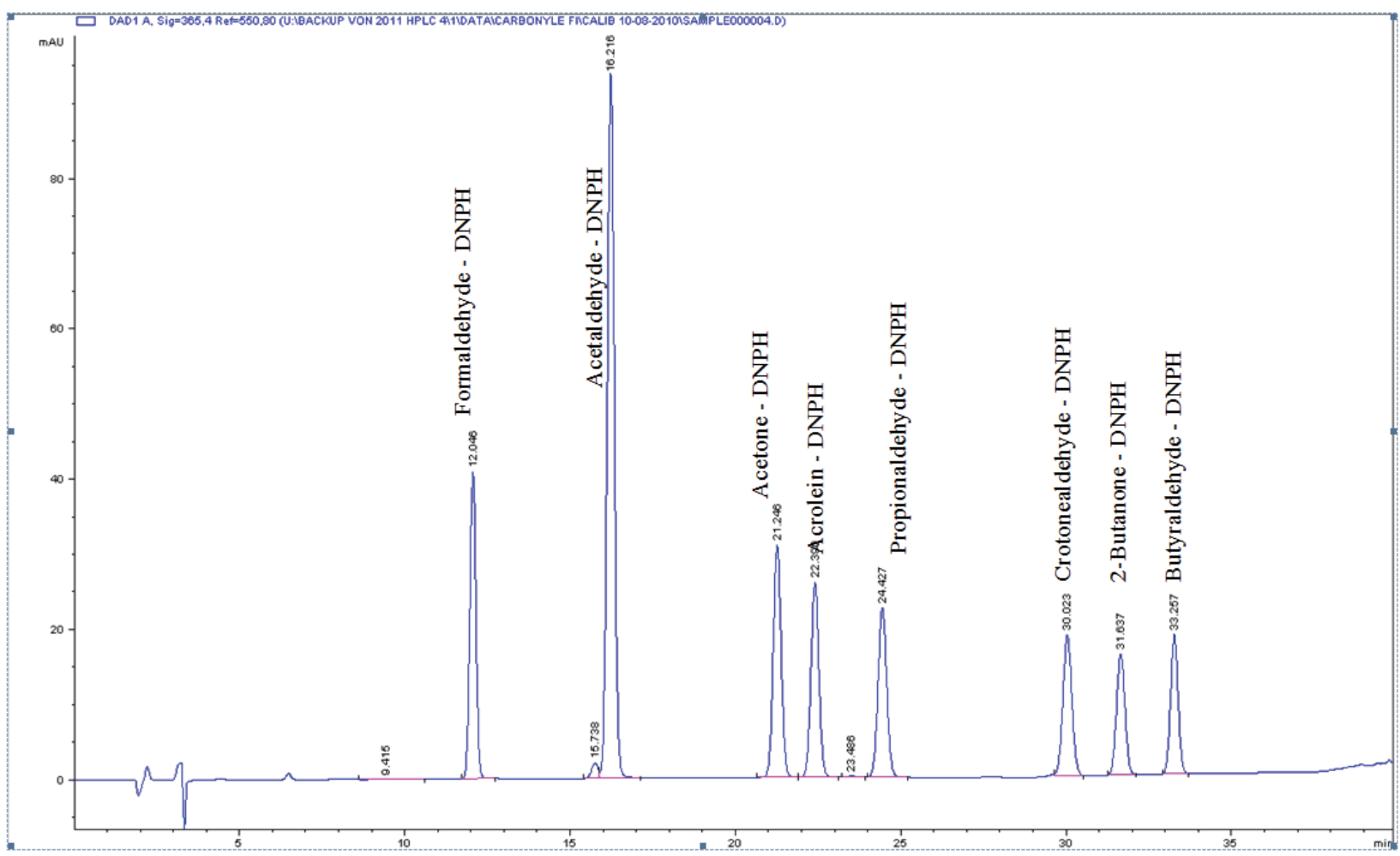

Figure 1. HPLC chromatogram of a typical combined carbonyl calibration standard. HPLC column used for this separation was an RP C $185 \mu \mathrm{m}, 250 \mathrm{~mm} \times 4.6 \mathrm{~mm}$.

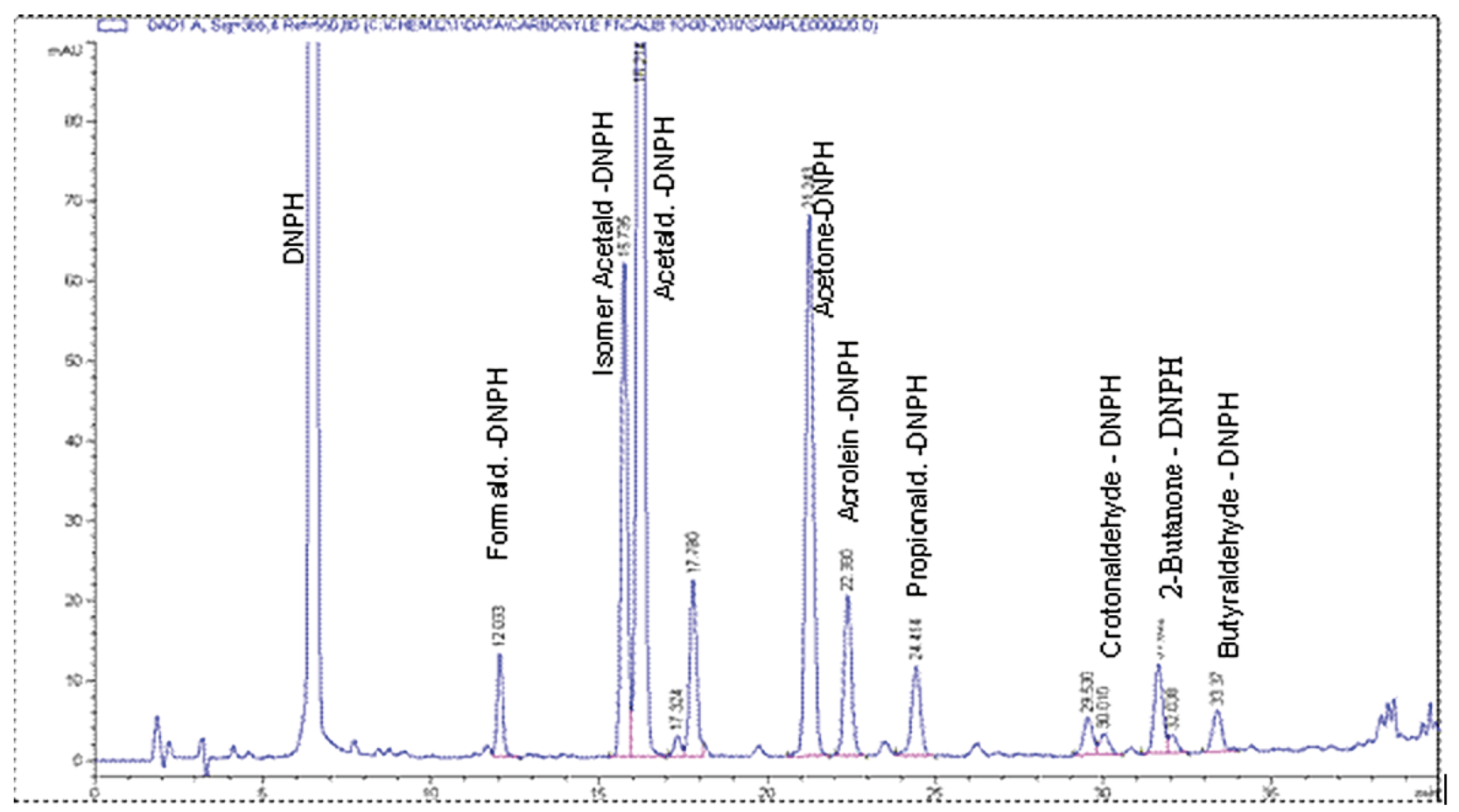

Figure 2. HPLC chromatogram of carbonyls in DNPH extract of mainstream smoke of 3R4F cigarettes. HPLC column used for this separation was an RP C $185 \mu \mathrm{m}, 250 \mathrm{~mm} \times 4.6 \mathrm{~mm}$. 
Table 8. Puff count data for the collaborative study. CoV = coefficient of variation.

\begin{tabular}{l|r|r}
\hline \multirow{2}{*}{ Sample code } & \multicolumn{2}{|c}{ Puffs } \\
\cline { 2 - 3 } & Mean & CoV\% \\
\hline CM6 & 9.6 & 3.5 \\
1R5F & 7.1 & 3.3 \\
3R4F & 8.6 & 3.1 \\
Sample 1 & 5.9 & 3.2 \\
Sample 2 & 10.0 & 5.4 \\
Sample 3 & 7.1 & 4.1 \\
Sample 4 & 6.7 & 3.8 \\
Sample 5 & 7.5 & 3.8 \\
\hline
\end{tabular}

studied products. Laboratory 1 provided data on the reference cigarettes (1R5F and 3R4F) and the CORESTA monitor cigarette (CM6). In total, 4600 data points were possible for the total of the 8 studied analytes.

\section{Variability of standard smoke parameters}

Puff count data were received from all participating laboratories and are summarised in Table 8 . The low puff count variability indicated good adherence to the ISO conditioning standard (12) by the participating laboratories. The highest variability in TPM yields was associated with the lowest yielding cigarette types i.e., 1R5F and Sample 4.

Table 9 shows the effect of the two different smoking machine types used in the laboratories on selected carbonyl yields. Seven laboratories used "linear" and 8 used "rotary" smoking machines for smoke collection. Different kinds of rotary and linear smoking machines are available and most yield differences are not statistically significant. For acetone, acrolein and crotonaldehyde, the smoking machine was a statistically significant factor affecting the difference in mean analyte yield and in most cases rotary smoking machines appear to produce higher yields than linear smoking machines.
Statistical calculations were based on ISO guidelines $(16,17)$ and applied to determine estimates of repeatability (r) and reproducibility $(\mathrm{R})$ of smoke yields where all of the participating laboratories used the same analytical method (11).

Data on all 8 samples was collected from 14 laboratories. One other laboratory supplied data on just the three reference cigarettes (CM6, 1R5F and 3R4F). In total, 575 data points were possible for each of the 8 studied analytes.

\section{Determination of inter-laboratory repeatability and reproducibility variance}

For each of the test samples the general mean was determined according to ISO 5725-2 section 7.4.4 (17) over the participating labs whose data remained following the removal of outliers. The outlier analysis methods are discussed in the following sections.

Repeatability was determined according to ISO 5725-2 section 7.4.5.1 and reproducibility variance as per ISO 57252 section 7.4.5.5 (17).

\section{Data below the limits of quantification}

Some individual data points were reported as non-numeric (i.e., below the LOQ) and had to be removed prior to evaluation of numeric data for outliers.

- Data for crotonaldehyde was below the LOD for Sample 4 and 1R5F from Laboratory 7.

- Only 4 of the 5 replicates were above the LOD for crotonaldehyde for 1R5F from Laboratory 13.

Thus, only 4589 data points in total across the 8 studied analytes were collected.

\section{Excluded outlier data}

All variance and mean outliers (1\%) determined by Grubbs' and Cochrans' tests were excluded prior to determination of the repeatability (r) and reproducibility (R). A summary of outliers is given in Table 10 .

Table 9. Effect of smoking machine type on carbonyl yields.

\begin{tabular}{|c|c|c|c|c|c|c|c|}
\hline Sample & $\begin{array}{l}\text { Smoking } \\
\text { machine }\end{array}$ & $\leq$ No. Labs & $\begin{array}{c}\text { Acetaldehyde } \\
(\mu \mathrm{g} / \mathrm{cig})\end{array}$ & $\begin{array}{r}\text { Acetone } \\
(\mu \mathrm{g} / \mathrm{cig})\end{array}$ & $\begin{array}{c}\text { Acrolein } \\
(\mu \mathrm{g} / \mathrm{cig})\end{array}$ & $\begin{array}{c}\text { Crotonaldehyde } \\
(\mu \mathrm{g} / \mathrm{cig})\end{array}$ & $\begin{array}{c}\text { Formaldehyde } \\
(\mu \mathrm{g} / \mathrm{cig})\end{array}$ \\
\hline \multirow{2}{*}{ CM6 } & linear & 7 & 666 & 252 & 61 & 19 & 43 \\
\hline & rotary & 8 & 629 & 250 & 65 & 23 & 43 \\
\hline \multirow{2}{*}{ 1R5F } & linear & 7 & 142 & 57 & 9 & 2 & 3 \\
\hline & rotary & 8 & 140 & 67 & 10 & 3 & 3 \\
\hline \multirow{2}{*}{ 3R4F } & linear & 7 & 541 & 198 & 45 & 11 & 19 \\
\hline & rotary & 8 & 536 & 214 & 50 & 15 & 18 \\
\hline \multirow{2}{*}{ Sample 1} & linear & 6 & 498 & 191 & 39 & 15 & 17 \\
\hline & rotary & 8 & 495 & 205 & 45 & 18 & 14 \\
\hline \multirow{2}{*}{ Sample 2} & linear & 6 & 350 & 139 & 29 & 7 & 9 \\
\hline & rotary & 8 & 330 & 148 & 31 & 8 & 8 \\
\hline \multirow{2}{*}{ Sample 3} & linear & 6 & 453 & 163 & 37 & 12 & 23 \\
\hline & rotary & 8 & 439 & 177 & 41 & 15 & 23 \\
\hline \multirow{2}{*}{ Sample 4} & linear & 6 & 83 & 29 & 5 & 1 & 2 \\
\hline & rotary & 8 & 89 & 42 & 7 & 2 & 2 \\
\hline \multirow{2}{*}{ Sample 5} & linear & 6 & 520 & 172 & 42 & 10 & 28 \\
\hline & rotary & 8 & 536 & 190 & 48 & 13 & 27 \\
\hline
\end{tabular}


Table 10. Variance and mean outliers.

\begin{tabular}{|c|c|c|c|}
\hline \multirow{2}{*}{ Sample } & \multirow{2}{*}{ Analyte } & \multicolumn{2}{|c|}{ Labs with outliers } \\
\hline & & Variance & Mean \\
\hline \multirow[t]{2}{*}{ Sample 1} & acetaldehyde & 13 & - \\
\hline & propionaldehyde & 23 & - \\
\hline \multirow[t]{6}{*}{ Sample 2} & acetaldehyde & 23 & - \\
\hline & acetone & 23 & - \\
\hline & propionaldehyde & 23 & - \\
\hline & crotonaldehyde & 20,23 & - \\
\hline & 2-butanone & 23 & - \\
\hline & butyraldehyde & 23 & - \\
\hline \multirow[t]{3}{*}{ Sample 3} & propionaldehyde & 8 & - \\
\hline & crotonaldehyde & 8,20 & - \\
\hline & butyraldehyde & 23 & - \\
\hline Sample 4 & butyraldehyde & 23 & - \\
\hline \multirow[t]{7}{*}{ Sample 5} & formaldehyde & 23 & - \\
\hline & acetaldehyde & $5,13,20$ & - \\
\hline & acetone & 5 & - \\
\hline & acrolein & 5 & - \\
\hline & propionaldehyde & $5,13,20$ & - \\
\hline & crotonaldehyde & 20 & - \\
\hline & butyraldehyde & 5,20 & - \\
\hline \multirow[t]{4}{*}{ CM6 } & formaldehyde & 23 & - \\
\hline & acetaldehyde & 2,13 & - \\
\hline & propionaldehyde & 23 & - \\
\hline & crotonaldehyde & $2,8,13+12^{a}$ & 20 \\
\hline \multirow[t]{3}{*}{ 1R5F } & acrolein & 5 & - \\
\hline & propionaldehyde & 13 & - \\
\hline & butyraldehyde & $23+13^{a}$ & - \\
\hline \multirow[t]{2}{*}{$3 \mathrm{R} 4 \mathrm{~F}$} & crotonaldehyde & 8 & - \\
\hline & butyraldehyde & 8 & - \\
\hline
\end{tabular}

a Single oberservation

After exclusion of the 232 outlier data points (5.1\%) from the total of 4589 data points, the mean smoke yields obtained from each laboratory were summarised in Table 5 and the overall mean yields and levels of repeatability and reproducibility of the studied carbonyls across each of the cigarette types were summarised in Table 11 (see page 374).

ISO 8243 (18) gives a practically relevant measurement tolerance with an expectation that declared yields of only $5 \%$ of brands tested would be outside of the limits (that is, the greater of $\pm 15 \%$ or, $\pm 1 \mathrm{mg}$ for NFDPM or, $\pm 0.1 \mathrm{mg}$ for nicotine). When expressing the ' $R$ ' value as a percentage of the mean across all of the studied products, values ranged from $67-125 \%$ for formaldehyde; from $24-55 \%$ for acetaldehyde; from $41-108 \%$ for acetone; from $45-73 \%$ for acrolein; from $63-140 \%$ for crotonaldehyde; from $31-75 \%$ for propionaldehyde; from $62-90 \%$ for 2-butanone and from $42-58 \%$ for butyraldehyde. The carbonyl yield reproducibility for the higher yielding products is worse than for NFDPM and nicotine which is in the range from $10-20 \%$ as given in ISO 8243 . The lowest "tar" yielding product (Sample 4) gave the most variable data. For the higher NFDPM yielding products the levels of carbonyl variability were in line with those previously evaluated during work on CRMs for benzo[ $a]$ pyrene (19) and tobacco specific nitrosamines (20).

\section{CONCLUSIONS}

The CORESTA SASG has developed a CRM that has optimised several components of the methodology that contribute to variability of test results.

The relative levels of reproducibility among laboratories for the studied analytes are much greater than the levels found for "tar", nicotine and carbon monoxide given in ISO 4387 (21). For the higher "tar" yielding products the levels of variability were in line with those previously evaluated during work on standard methods for benzo[a]pyrene and tobacco specific nitrosamines. The lowest "tar" yielding product (Sample 4) gave the most variable data.

\section{ACKNOWLEDGEMENTS}

The Special Analytes Sub-Group (SASG) co-ordinators wish to acknowledge the contributions of each principal investigator and their colleagues without which the work of the Sub-Group could not have been completed.

The co-ordinators also wish to acknowledge the contributions made by other members who participated in the earlier joint experiment and to other members who joined in the productive meeting discussions and helped with the production of the CORESTA recommended method (CRM). These were Fraser Williamson (Arista USA), Tatiana Humphries (Arista Laboratories Europe), Waldenir Farias Braga (BAT, Brazil), Walther Klerx (Food Consumer Product Safety, Netherlands) and Katrin Schade (Borgwaldt, Germany).

\section{REFERENCES}

1. Intorp, M. and S.W. Purkis: Determination of Selected Volatiles in Cigarette Mainstream Smoke. The CORESTA 2008 Joint Experiment; Beitr. Tabakforsch. Int. 24 (2011) 174-186.

2. Intorp, M., S.W. Purkis, and W. Wagstaff: Determination of Selected Volatiles in Cigarette Mainstream Smoke. The CORESTA 2009 Collaborative Study and Recommended Method; Beitr. Tabakforsch. Int. 24 (2011) 243-251.

3. Manning, D.L., M.P. Maskerinec, R.A. Jenkins, and A.H. Marshall: High Performance Liquid Chromatographic Determinations of Selected Gas Phase Carbonyls in Tobacco Smoke; J. Assoc. Off. Anal. Chem 66 (1983) 8-12.

4. Borgerding, M.F., R.S. Dunn, F.A. Thome, H.L. Chung, D.S. Moore, T.R. Conner, D.L. Heavner, and P.H. Ayers: An Improved Method for the Determination of Selected Carbonyl Compounds in Smoke. $38^{\text {th }}$ Tobacco Chemists' Research Conference, Atlanta, GA, November 5-8, 1984, Paper 50; Bates-No. 519974689-4712, available at http://legacy.library.ucsf.edu/tid/xig31d00 (accessed June 2012). 
5. Houlgate, P.R., K.S. Dhingra, J.S. Nash, and W.H. Evans: Determination of Formaldehyde and Acetaldehyde in Mainstream Cigarette Smoke by High-Performance Liquid Chromatography; Analyst 114 (1989) 355-360.

6. Health Canada: Official Method T-104-Determination of Selected Carbonyls in Mainstream Tobacco Smoke 1999; available at http://www.hc-sc.gc.ca/hc-ps/tobactabac/legislation/reg/indust/method/_main-principal/ carbonyl-eng.php (accessed June 201 $\overline{2}$ ).

7. Dong, J.-Z. and S.C. Moldoveanu: Gas Chromatography - Mass Spectrometry of Carbonyl Compounds in Cigarette Mainstream Smoke After Derivatisation with 2,4-dinitrophenylhydrazine; J. Chromatogr. A 1027 (2004) 25-35.

8. Intorp, M.: Studies on Alternative Analytical Methods for the Determination of Organic Compounds in the Gas Phase of Mainstream Cigarette Smoke; Presentation Made at the 2002 CORESTA Congress in New Orleans, USA, Smoke Science and Product Technology, ST 29, 2002.

9. Intorp, M., S. Purkis, M. Whittaker, and W. Wright: Determination of "Hoffmann Analytes" in Cigarette Mainstream Smoke. The CORESTA 2006 Joint Experiment; Beitr. Tabakforsch. Int. 23 (2009) 161-202.

10.University of Kentucky, College of Agriculture: Reference Cigarette Program; available at http://www.ca.uky. edu/refcig/ (accessed June 2012).

11.CORESTA Recommended Method No. 74: Determination of Selected Carbonyls in Mainstream Cigarette Smoke by High Performance Liquid Chromatography (HPLC) August 2011; available at http://www.coresta. org (accessed June 2012).

12.International Organization for Standardization: ISO 3402:1999 - Tobacco and Tobacco Products - Atmosphere for Conditioning and Testing; ISO, Geneva, Switzerland, 1999.

13.International Organization for Standardization: ISO 3308:2000 - Routine Analytical Cigarette-smoking Machine - Definitions and Standard Conditions; ISO, Geneva, Switzerland, 2000.

14. Uchiyama, S., M. Ando, and S. Aoyagi: Isomerization of Aldehyde-2,4-dinitrophenylhydrazone Derivatives and Validation of High-performance Liquid Chromatographic Analysis; J. Chromatogr. A 996 (2003) 95-102.

15.European Commission, DG SANCO: Method Valida- tion and Quality Control Procedures for Pesticide Residues Analysis in Food and Feed; Sanco Document / 10684 / 2009; available at http://ec.europa.eu/food/ plant/protection/resources/qualcontrol_en.pdf(accessed June 2012).

16.International Organization for Standardization: ISO 5725-1:1994 - Accuracy (Trueness and Precision) of Measurement Methods and Results - Part 1: General Principles and Definitions; ISO, Geneva, Switzerland, 1994.

17.International Organization for Standardization: ISO 5725-2:1994 - Accuracy (Trueness and Precision) of Measurement Methods and Results - Part 2: Basic Method for the Determination of Repeatability and Reproducibility of a Standard Measurement Method; ISO, Geneva, Switzerland, 1994.

18. International Organization for Standardization: ISO 8243:2006 - Cigarettes - Sampling; ISO, Geneva, Switzerland, 2006.

19. CORESTA Recommended Method No. 58: Determination of Benzo $[a]$ pyrene in Cigarette Mainstream Smoke - Gas Chromatography-Mass Spectrometry Method, 2004; available at http://www.coresta.org (accessed June 2012).

20.CORESTA Recommended Method No. 63: Determination of Tobacco Specific Nitrosamines in Cigarette Mainstream Smoke - GC-TEA Method, 2005; available at http://www.coresta.org/ (accessed June 2012).

21.International Organization for Standardization: ISO 4387:2000 - Cigarettes - Determination of Total and Nicotine-free Dry Particulate Matter Using A Routine Analytical Smoking Machine; ISO, Geneva, Switzerland, 2000.

\section{Corresponding author:}

Steve Purkis

Imperial Tobacco Limited

PO Box 525,

Winterstoke Road

Bristol BS99 $1 L Q$

UK

steve.purkis@uk.imptob.com 


\section{APPENDIX}

\section{Table 5. Carbonyl yield data.}

The following Tables 5.1. to 5.8. use the following codes:

$\ddagger \quad$ average of 4 replicates given in the following tables after removal of one replicate outlier

\# outlier data - not used in the calculation of $r$ and $R$ values

Table 5.1. Kentucky Reference (3R4F) cigarettes - mean yields from each laboratory in $\mu \mathrm{g} / \mathrm{cig}$.

\begin{tabular}{|c|c|c|c|c|c|c|c|c|}
\hline Lab & $\begin{array}{c}\text { Form- } \\
\text { aldehyde }\end{array}$ & $\begin{array}{c}\text { Acet- } \\
\text { aldehyde }\end{array}$ & Acetone & Acrolein & $\begin{array}{l}\text { Propion- } \\
\text { aldehyde }\end{array}$ & $\begin{array}{l}\text { Croton- } \\
\text { aldehyde }\end{array}$ & 2-Butanone & $\begin{array}{c}\text { Butyr- } \\
\text { aldehyde }\end{array}$ \\
\hline 1 & 17.26 & 455.96 & 193.12 & 37.18 & 31.04 & 7.00 & 43.58 & 20.48 \\
\hline 2 & 13.43 & 438.41 & 204.61 & 48.10 & 39.02 & 18.26 & 54.09 & 26.51 \\
\hline 5 & 24.69 & 615.60 & 244.45 & 57.11 & 41.97 & 9.68 & 58.75 & 28.75 \\
\hline 7 & 23.61 & 590.60 & 206.61 & 52.11 & 40.97 & 8.71 & 43.33 & 24.72 \\
\hline 8 & 19.90 & 497.59 & 140.72 & 36.08 & 38.89 & $26.05 \#$ & 32.41 & $27.80 \#$ \\
\hline 9 & 15.48 & 491.17 & 160.55 & 37.92 & 34.81 & 7.48 & 36.47 & 24.28 \\
\hline 11 & 21.72 & 513.98 & 209.84 & 47.71 & 39.13 & 12.11 & 36.57 & 27.58 \\
\hline 12 & 24.93 & 536.26 & 204.56 & 52.04 & 45.32 & 18.28 & 45.88 & 26.45 \\
\hline 13 & 19.54 & 631.00 & 220.26 & 55.42 & 43.26 & 10.51 & 50.05 & 22.07 \\
\hline 14 & 23.91 & 581.38 & 269.22 & 63.48 & 47.77 & 13.30 & 68.74 & 29.09 \\
\hline 17 & 19.19 & 560.80 & 215.77 & 48.01 & 45.10 & 9.73 & 64.01 & 29.30 \\
\hline 18 & 14.56 & 576.68 & 222.71 & 43.04 & 39.28 & 10.85 & 50.50 & 25.97 \\
\hline 19 & 15.26 & 482.69 & 190.75 & 52.39 & 34.84 & 8.68 & 42.38 & 27.48 \\
\hline 20 & 11.60 & 539.07 & 170.39 & 40.12 & 30.77 & $24.74 \#$ & 45.02 & 26.17 \\
\hline 23 & 16.77 & 564.08 & 242.33 & 43.86 & 44.72 & 10.06 & 47.91 & 38.13 \\
\hline
\end{tabular}

Table 5.2. Kentucky Reference (1R5F) cigarettes - mean yields from each laboratory in $\mu \mathrm{g} / \mathrm{cig}$.

\begin{tabular}{|c|c|c|c|c|c|c|c|c|}
\hline Lab & $\begin{array}{c}\text { Form- } \\
\text { aldehyde }\end{array}$ & $\begin{array}{c}\text { Acet- } \\
\text { aldehyde }\end{array}$ & Acetone & Acrolein & $\begin{array}{l}\text { Propion- } \\
\text { aldehyde }\end{array}$ & $\begin{array}{c}\text { Croton- } \\
\text { aldehyde }\end{array}$ & 2-Butanone & $\begin{array}{c}\text { Butyr- } \\
\text { aldehyde }\end{array}$ \\
\hline 1 & 2.80 & 116.86 & 56.76 & 7.62 & 8.30 & 0.74 & 10.52 & 5.88 \\
\hline 2 & 1.26 & 119.94 & 58.61 & 9.45 & 10.34 & 2.99 & 12.87 & 7.89 \\
\hline 5 & 4.17 & 216.32 & 88.85 & $16.25 \#$ & 15.32 & 1.79 & 19.23 & 10.58 \\
\hline 7 & 3.23 & 121.15 & 45.46 & 7.49 & 8.82 & $<$ LOD & 8.40 & 6.10 \\
\hline 8 & 6.01 & 128.88 & 41.81 & 7.46 & 11.02 & 2.85 & 7.55 & 6.56 \\
\hline 9 & 3.19 & 125.04 & 45.32 & 7.55 & 9.20 & 1.44 & 9.23 & 7.15 \\
\hline 11 & 3.37 & 146.33 & 70.73 & 10.67 & 12.44 & 2.53 & 11.96 & 9.25 \\
\hline 12 & 3.53 & 148.22 & 64.44 & 11.23 & 14.11 & 3.73 & 13.86 & 8.05 \\
\hline 13 & 1.98 & 144.80 & 56.88 & 8.85 & $9.26 \#$ & 1.07 & 11.70 & $5.90 \neq$ \\
\hline 14 & 3.79 & 165.89 & 90.80 & 13.96 & 14.94 & 3.11 & 21.41 & 9.69 \\
\hline 17 & 2.33 & 131.49 & 54.41 & 8.59 & 11.41 & 1.07 & 14.32 & 7.80 \\
\hline 18 & 2.12 & 153.23 & 64.44 & 7.99 & 10.92 & 1.46 & 13.61 & 8.23 \\
\hline 19 & 2.24 & 122.42 & 56.74 & 11.31 & 9.83 & 1.40 & 10.98 & 7.66 \\
\hline 20 & 1.21 & 103.27 & 39.57 & 5.74 & 6.57 & $3.62 \#$ & 9.37 & 5.63 \\
\hline 23 & 3.79 & 169.93 & 95.08 & 10.50 & 14.43 & 2.33 & 14.71 & 13.63 \# \\
\hline
\end{tabular}


Table 5.3. CORESTA Monitor (CM6) cigarettes - mean yields from each laboratory in $\mu \mathrm{g} / \mathrm{cig}$.

\begin{tabular}{|c|c|c|c|c|c|c|c|c|}
\hline Lab & $\begin{array}{c}\text { Form- } \\
\text { aldehyde }\end{array}$ & $\begin{array}{c}\text { Acet- } \\
\text { aldehyde }\end{array}$ & Acetone & Acrolein & $\begin{array}{l}\text { Propion- } \\
\text { aldehyde }\end{array}$ & $\begin{array}{l}\text { Croton- } \\
\text { aldehyde }\end{array}$ & 2-Butanone & $\begin{array}{l}\text { Butyr- } \\
\text { aldehyde }\end{array}$ \\
\hline 1 & 40.50 & 597.22 & 249.68 & 53.20 & 40.28 & 12.84 & 56.44 & 30.22 \\
\hline 2 & 27.94 & $487.89 \#$ & 236.32 & 57.36 & 44.04 & 26.90 \# & 62.21 & 34.39 \\
\hline 5 & 54.84 & 734.57 & 307.44 & 73.29 & 51.55 & 17.08 & 75.91 & 40.48 \\
\hline 7 & 54.35 & 739.10 & 260.85 & 72.74 & 52.19 & 14.89 & 52.98 & 34.74 \\
\hline 8 & 37.50 & 584.96 & 183.89 & 49.64 & 49.83 & 33.85 \# & 39.38 & 32.97 \\
\hline 9 & 34.35 & 681.42 & 234.89 & 57.94 & 48.99 & 15.77 & 54.88 & 38.88 \\
\hline 11 & 51.85 & 587.08 & 241.71 & 60.81 & 46.35 & 18.93 & 40.27 & 35.17 \\
\hline 12 & 54.04 & 629.37 & 248.37 & 67.80 & 54.47 & $26.70 \ddagger$ & 58.20 & 35.84 \\
\hline 13 & 44.40 & $737.60 \#$ & 263.24 & 72.60 & 51.58 & 17.54 \# & 56.78 & 28.62 \\
\hline 14 & 52.70 & 653.67 & 305.36 & 80.29 & 52.91 & 20.61 & 76.22 & 36.29 \\
\hline 17 & 42.12 & 644.62 & 252.42 & 62.43 & 52.08 & 16.63 & 76.93 & 38.41 \\
\hline 18 & 34.92 & 677.85 & 274.89 & 55.24 & 47.45 & 19.30 & 61.75 & 36.05 \\
\hline 19 & 37.24 & 619.15 & 230.05 & 73.07 & 45.57 & 13.90 & 47.67 & 36.23 \\
\hline 20 & 30.77 & 660.40 & 200.64 & 57.01 & 41.24 & $38.81 \#$ & 58.07 & 41.99 \\
\hline 23 & $42.80 \#$ & 659.92 & 275.86 & 53.61 & $56.19 \#$ & 15.74 & 57.15 & 47.53 \\
\hline
\end{tabular}

Table 5.4. Sample 1 cigarettes - mean yields from each laboratory in $\mu \mathrm{g} / \mathrm{cig}$.

\begin{tabular}{|c|c|c|c|c|c|c|c|c|}
\hline Lab & $\begin{array}{c}\text { Form- } \\
\text { aldehyde }\end{array}$ & $\begin{array}{c}\text { Acet- } \\
\text { aldehyde }\end{array}$ & Acetone & Acrolein & $\begin{array}{l}\text { Propion- } \\
\text { aldehyde }\end{array}$ & $\begin{array}{c}\text { Croton- } \\
\text { aldehyde }\end{array}$ & 2-Butanone & $\begin{array}{c}\text { Butyr- } \\
\text { aldehyde }\end{array}$ \\
\hline 2 & 6.40 & 398.85 & 197.85 & 41.17 & 34.02 & 21.72 & 48.38 & 21.14 \\
\hline 5 & 21.06 & 585.59 & 253.14 & 51.23 & 39.35 & 15.49 & 61.91 & 25.26 \\
\hline 7 & 14.70 & 512.70 & 189.63 & 43.49 & 34.80 & 11.68 & 39.56 & 19.60 \\
\hline 8 & 17.17 & 395.87 & 127.86 & 28.46 & 32.18 & 23.91 & 36.19 & 28.35 \\
\hline 9 & 14.03 & 464.42 & 165.38 & 32.74 & 32.10 & 9.90 & 36.18 & 21.52 \\
\hline 11 & 19.55 & 457.31 & 197.24 & 42.27 & 35.69 & 17.13 & 31.43 & 21.52 \\
\hline 12 & 14.89 & 505.36 & 200.24 & 46.70 & 42.38 & 22.46 & 43.47 & 22.91 \\
\hline 13 & 17.08 & $644.20 \#$ & 223.96 & 52.66 & 42.42 & 16.16 & 47.28 & 18.56 \\
\hline 14 & 18.33 & 507.02 & 245.93 & 55.28 & 40.83 & 17.74 & 61.98 & 22.64 \\
\hline 17 & 21.29 & 521.62 & 203.86 & 41.63 & 40.61 & 13.44 & 62.96 & 24.66 \\
\hline 18 & 15.19 & 506.76 & 208.38 & 33.82 & 33.71 & 14.40 & 45.28 & 23.00 \\
\hline 19 & 7.53 & 465.98 & 189.75 & 48.55 & 34.73 & 12.25 & 40.53 & 23.05 \\
\hline 20 & 11.69 & 492.30 & 159.09 & 35.68 & 27.19 & $27.26 \#$ & 43.29 & 23.24 \\
\hline 23 & 13.07 & 488.15 & 227.81 & 34.42 & $41.73 \#$ & 12.49 & 44.74 & 31.54 \\
\hline
\end{tabular}

Table 5.5. Sample 2 cigarettes - mean yields from each laboratory in $\mu \mathrm{g} / \mathrm{cig}$.

\begin{tabular}{l|r|c|c|c|r|r|r|c}
\hline Lab & $\begin{array}{c}\text { Form- } \\
\text { aldehyde }\end{array}$ & $\begin{array}{c}\text { Acet- } \\
\text { aldehyde }\end{array}$ & Acetone & Acrolein & $\begin{array}{c}\text { Propion- } \\
\text { aldehyde }\end{array}$ & $\begin{array}{c}\text { Croton- } \\
\text { aldehyde }\end{array}$ & 2-Butanone & $\begin{array}{c}\text { Butyr- } \\
\text { aldehyde }\end{array}$ \\
\hline 2 & 6.10 & 282.18 & 139.79 & 29.93 & 25.74 & 10.13 & 33.49 & 17.75 \\
5 & 12.19 & 432.57 & 188.04 & 41.12 & 31.51 & 6.31 & 43.98 & 21.81 \\
7 & 9.66 & 338.83 & 127.66 & 28.95 & 25.34 & 3.75 & 25.42 & 16.16 \\
8 & 9.49 & 287.31 & 97.20 & 21.06 & 25.23 & 14.11 & 20.17 & 20.40 \\
9 & 7.14 & 313.31 & 114.63 & 24.54 & 23.80 & 4.89 & 24.91 & 17.51 \\
11 & 8.98 & 315.66 & 145.14 & 27.75 & 24.96 & 7.07 & 25.10 & 18.82 \\
12 & 10.71 & 331.26 & 139.68 & 31.43 & 31.89 & 10.50 & 30.70 & 18.06 \\
13 & 8.16 & 375.60 & 145.90 & 32.98 & 27.38 & 5.26 & 31.90 & 14.46 \\
14 & 10.78 & 359.54 & 184.23 & 39.60 & 32.26 & 7.66 & 46.32 & 19.78 \\
17 & 7.70 & 342.59 & 143.41 & 29.20 & 29.31 & 4.88 & 40.32 & 19.77 \\
18 & 6.46 & 383.26 & 161.29 & 27.59 & 28.10 & 6.79 & 35.89 & 19.60 \\
19 & 7.15 & 305.21 & 135.37 & 34.28 & 24.83 & 4.86 & 29.02 & 19.38 \\
20 & 4.26 & 293.12 & 108.17 & 20.32 & 19.62 & 13.57 \# & 27.52 & 15.91 \\
23 & 8.63 & $376.56 \#$ & $185.90 \#$ & 29.22 & $31.97 \#$ & $6.10 \#$ & $35.05 \#$ & 30.08 \# \# \\
\hline
\end{tabular}


Table 5.6. Sample 3 cigarettes - mean yields from each laboratory in $\mu \mathrm{g} / \mathrm{cig}$.

\begin{tabular}{|c|c|c|c|c|c|c|c|c|}
\hline Lab & $\begin{array}{l}\text { Form- } \\
\text { aldehyde }\end{array}$ & $\begin{array}{c}\text { Acet- } \\
\text { aldehyde }\end{array}$ & Acetone & Acrolein & $\begin{array}{l}\text { Propion- } \\
\text { aldehyde }\end{array}$ & $\begin{array}{l}\text { Croton- } \\
\text { aldehyde }\end{array}$ & 2-Butanone & $\begin{array}{c}\text { Butyr- } \\
\text { aldehyde }\end{array}$ \\
\hline 2 & 20.71 & 380.50 & 176.90 & 42.50 & 33.06 & 19.85 & 45.82 & 24.66 \\
\hline 5 & 30.87 & 497.15 & 198.68 & 46.15 & 33.60 & 9.69 & 49.12 & 25.19 \\
\hline 7 & 29.98 & 480.94 & 168.13 & 43.94 & 33.09 & 9.28 & 36.81 & 22.24 \\
\hline 8 & 19.18 & 364.82 & 109.72 & 28.07 & $27.59 \#$ & $22.85 \#$ & 25.18 & 29.07 \\
\hline 9 & 18.70 & 449.31 & 146.44 & 33.90 & 32.15 & 8.97 & 33.50 & 24.00 \\
\hline 11 & 25.42 & 428.74 & 178.58 & 40.02 & 32.11 & 14.03 & 32.31 & 24.32 \\
\hline 12 & 30.68 & 448.54 & 173.54 & 43.44 & 38.24 & 18.91 & 40.57 & 24.87 \\
\hline 13 & 19.52 & 468.20 & 165.70 & 40.26 & 31.24 & 9.72 & 37.84 & 17.54 \\
\hline 14 & 31.23 & 473.80 & 221.35 & 52.64 & 38.48 & 14.34 & 58.58 & 25.79 \\
\hline 17 & 21.17 & 461.20 & 176.13 & 39.41 & 36.23 & 10.83 & 55.32 & 26.17 \\
\hline 18 & 18.54 & 463.32 & 180.25 & 33.17 & 30.78 & 11.12 & 41.18 & 23.18 \\
\hline 19 & 19.25 & 406.63 & 160.62 & 43.64 & 29.67 & 9.18 & 36.26 & 24.60 \\
\hline 20 & 14.14 & 426.45 & 136.72 & 30.69 & 25.82 & $20.02 \#$ & 34.49 & 21.74 \\
\hline 23 & 20.40 & 475.86 & 204.64 & 36.90 & 37.64 & 10.00 & 40.58 & 34.93 \# \\
\hline
\end{tabular}

Table 5.7. Sample 4 cigarettes - mean yields from each laboratory in $\mu \mathrm{g} / \mathrm{cig}$.

\begin{tabular}{r|c|c|c|c|c|c|c|c}
\hline Lab & $\begin{array}{c}\text { Form- } \\
\text { aldehyde }\end{array}$ & $\begin{array}{c}\text { Acet- } \\
\text { aldehyde }\end{array}$ & Acetone & Acrolein & $\begin{array}{c}\text { Propion- } \\
\text { aldehyde }\end{array}$ & $\begin{array}{c}\text { Croton- } \\
\text { aldehyde }\end{array}$ & 2-Butanone & $\begin{array}{c}\text { Butyr- } \\
\text { aldehyde }\end{array}$ \\
\hline 2 & 1.60 & 81.88 & 38.34 & 7.25 & 6.83 & 2.42 & 8.01 & 5.09 \\
5 & 1.91 & 92.84 & 35.18 & 6.76 & 6.53 & 0.58 & 7.06 & 4.80 \\
7 & 2.69 & 85.53 & 29.56 & 5.76 & 5.76 & - & 5.19 & 4.42 \\
8 & 3.75 & 69.06 & 16.09 & 3.83 & 4.61 & 1.52 & 3.33 & 2.65 \\
9 & 2.57 & 76.62 & 27.09 & 5.07 & 5.45 & 0.83 & 5.08 & 4.05 \\
11 & 2.82 & 80.49 & 36.74 & 6.39 & 6.82 & 1.76 & 6.28 & 5.09 \\
12 & 2.18 & 83.87 & 36.11 & 6.26 & 7.82 & 1.83 & 7.46 & 4.66 \\
13 & 2.27 & 105.20 & 34.36 & 7.25 & 7.79 & 1.29 & 8.00 & 4.17 \\
14 & 3.01 & 99.31 & 54.56 & 9.12 & 8.86 & 2.34 & 12.29 & 5.90 \\
17 & 1.42 & 72.62 & 27.49 & 4.74 & 5.94 & 0.59 & 6.82 & 4.03 \\
18 & 1.57 & 99.11 & 39.34 & 5.51 & 6.73 & 0.99 & 8.16 & 5.02 \\
19 & 1.64 & 72.69 & 34.92 & 6.74 & 5.92 & 0.96 & 6.55 & 4.60 \\
20 & 0.93 & 70.99 & 27.62 & 4.20 & 4.16 & $2.45 \#$ & 6.26 & 3.75 \\
23 & 4.50 & 120.05 & 73.16 & 7.62 & 10.35 & 1.82 & 9.73 & $9.53 \#$ \\
\hline
\end{tabular}

Table 5.8. Sample 5 cigarettes - mean yields from each laboratory in $\mu \mathrm{g} / \mathrm{cig}$.

\begin{tabular}{l|c|c|c|c|c|c|c|c}
\hline Lab & $\begin{array}{c}\text { Form- } \\
\text { aldehyde }\end{array}$ & $\begin{array}{c}\text { Acet- } \\
\text { aldehyde }\end{array}$ & Acetone & Acrolein & $\begin{array}{c}\text { Propion- } \\
\text { aldehyde }\end{array}$ & $\begin{array}{c}\text { Croton- } \\
\text { aldehyde }\end{array}$ & 2-Butanone & $\begin{array}{c}\text { Butyr- } \\
\text { aldehyde }\end{array}$ \\
\hline 2 & 17.03 & 395.69 & 175.3 & 42.85 & 33.20 & 15.94 & 40.37 & 21.47 \\
5 & 38.20 & $581.50 \#$ & $207.5 \#$ & $52.38 \#$ & $36.65 \#$ & 7.86 & 42.69 & $22.88 \#$ \\
7 & 31.26 & 539.74 & 169.4 & 45.44 & 35.05 & 6.65 & 29.90 & 19.09 \\
8 & 29.51 & 461.84 & 127.1 & 34.78 & 36.63 & 22.72 & 26.20 & 30.26 \\
9 & 22.79 & 523.94 & 167.6 & 40.05 & 35.11 & 8.38 & 34.73 & 22.90 \\
11 & 34.50 & 496.00 & 194.1 & 47.12 & 36.43 & 12.26 & 30.67 & 23.03 \\
12 & 31.29 & 500.12 & 172.9 & 45.76 & 39.78 & 15.03 & 33.79 & 21.11 \\
13 & 26.97 & $610.40 \#$ & 193.4 & 51.60 & $38.40 \#$ & 9.63 & 40.88 & 18.07 \\
14 & 40.54 & 576.44 & 252.1 & 64.98 & 45.11 & 13.55 & 58.32 & 25.64 \\
17 & 25.64 & 491.50 & 168.0 & 39.62 & 36.15 & 7.48 & 43.65 & 21.74 \\
18 & 22.53 & 519.55 & 191.9 & 38.00 & 34.24 & 9.23 & 38.50 & 21.02 \\
19 & 22.82 & 505.22 & 186.0 & 54.50 & 35.36 & 8.71 & 37.10 & 25.83 \\
20 & 16.58 & $515.06 \#$ & 147.9 & 38.69 & $31.53 \#$ & $20.0 \#$ & 35.32 & $22.61 \#$ \\
23 & $24.66 \#$ & 510.14 & 195.0 & 34.27 & 38.40 & 6.7 & 32.50 & 29.86 \\
\hline
\end{tabular}


Table 11. Mean yields, repeatability ('r') and reproducibility ('R') data obtained using the CORESTA recommended method.

\begin{tabular}{|c|c|c|c|c|c|c|c|c|c|c|c|c|c|c|c|c|}
\hline \multirow{2}{*}{ Sample } & \multicolumn{4}{|c|}{ Formaldehyde } & \multicolumn{4}{|c|}{ Acetaldehyde } & \multicolumn{4}{|c|}{ Acetone } & \multicolumn{4}{|c|}{ Acrolein } \\
\hline & $\mathrm{NL}^{a}$ & $M^{b}$ & ' $r{ }^{\prime c}$ & ${ }^{\prime} R^{\prime d}$ & $\mathrm{NL}$ & $\mathrm{M}$ & 'r' & 'R' & $\mathrm{NL}$ & $\mathrm{M}$ & 'r' & 'R' & $\mathrm{NL}$ & $\mathrm{M}$ & 'r' & 'R' \\
\hline 1 & 14 & 15.1 & 5.4 & 13.6 & 13 & 485 & 77 & 158 & 14 & 199 & 31 & 99 & 14 & 42.0 & 7.3 & 24.1 \\
\hline 2 & 14 & 8.4 & 3.1 & 6.6 & 13 & 335 & 60 & 134 & 13 & 141 & 26 & 78 & 14 & 29.9 & 7.0 & 18.0 \\
\hline 3 & 14 & 22.8 & 7.6 & 17.4 & 14 & 445 & 79 & 131 & 14 & 171 & 33 & 85 & 14 & 39.6 & 8.4 & 20.1 \\
\hline 4 & 14 & 2.4 & 1.3 & 3.0 & 14 & 86 & 22 & 47 & 14 & 37 & 11 & 40 & 14 & 6.2 & 2.2 & 4.5 \\
\hline 5 & 13 & 27.7 & 8.2 & 22.3 & 11 & 502 & 56 & 139 & 13 & 180 & 33 & 88 & 13 & 44.4 & 7.8 & 25.5 \\
\hline CM 6 & 14 & 42.7 & 12.1 & 28.7 & 13 & 651 & 77 & 156 & 15 & 251 & 48 & 104 & 15 & 63.1 & 11.8 & 28.6 \\
\hline $1 \mathrm{R} 5 \mathrm{~F}$ & 15 & 3.0 & 1.2 & 3.7 & 15 & 141 & 37 & 86 & 15 & 62 & 16 & 52 & 14 & 9.2 & 2.7 & 6.6 \\
\hline $3 R 4 F$ & 15 & 18.8 & 4.9 & 13.0 & 15 & 538 & 79 & 177 & 15 & 206 & 35 & 99 & 15 & 47.6 & 8.1 & 23.7 \\
\hline \multirow[t]{2}{*}{ Sample } & \multicolumn{4}{|c|}{ Propionaldehyde } & \multicolumn{4}{|c|}{ Crotonaldehyde } & \multicolumn{4}{|c|}{ 2-Butanone } & \multicolumn{4}{|c|}{ Butyraldehyde } \\
\hline & $\mathrm{NL}$ & $\mathrm{M}$ & 'r' & 'R' & $\mathrm{NL}$ & $\mathrm{M}$ & 'r' & 'R' & $\mathrm{NL}$ & $\mathrm{M}$ & 'r' & 'R' & $\mathrm{NL}$ & $\mathrm{M}$ & 'r' & 'R' \\
\hline 1 & 13 & 36.2 & 6.7 & 14.4 & 14 & 16.9 & 3.9 & 15.1 & 14 & 45.9 & 9.6 & 29.5 & 14 & 23.4 & 5.8 & 10.8 \\
\hline 2 & 13 & 26.9 & 4.7 & 11.1 & 12 & 7.2 & 2.1 & 8.8 & 13 & 31.9 & 6.2 & 23.0 & 13 & 18.4 & 4.3 & 6.9 \\
\hline 3 & 13 & 32.2 & 7.2 & 12.2 & 12 & 12.2 & 3.6 & 11.2 & 14 & 40.5 & 9.3 & 27.0 & 13 & 24.1 & 5.7 & 9.2 \\
\hline 4 & 14 & 6.7 & 2.1 & 5.0 & 13 & 1.5 & 0.9 & 2.1 & 14 & 7.2 & 2.6 & 6.5 & 13 & 4.5 & 1.4 & 2.6 \\
\hline 5 & 11 & 36.9 & 5.3 & 10.4 & 13 & 11.1 & 3.2 & 13.5 & 14 & 37.5 & 11.3 & 24.4 & 12 & 23.3 & 4.3 & 11.6 \\
\hline CM 6 & 14 & 48.5 & 9.3 & 15.1 & 11 & 19.1 & 3.5 & 12.1 & 15 & 58.3 & 16.9 & 35.9 & 15 & 36.5 & 8.6 & 15.2 \\
\hline 1R5F & 14 & 11.3 & 2.9 & 8.0 & 14 & 2.2 & 1.0 & 3.0 & 15 & 12.6 & 4.1 & 11.4 & 14 & 7.6 & 1.9 & 4.6 \\
\hline $3 R 4 F$ & 15 & 39.8 & 6.3 & 15.7 & 14 & 12.1 & 2.7 & 14.4 & 15 & 48.0 & 9.5 & 30.0 & 14 & 26.9 & 4.6 & 12.3 \\
\hline
\end{tabular}

\footnotetext{
$\mathrm{NL}=$ number of laboratories used to provide mean, repeatability and reproducibility data

$\mathrm{M}=$ mean yield $(\mu \mathrm{g} /$ cigarette)

' $r$ ' = repeatability ( $\mu \mathrm{g} /$ cigarette at $95 \%$ confidence interval)

' $R$ ' = reproducibility ( $\mu \mathrm{g} /$ cigarette at $95 \%$ confidence interval)
} 